\title{
ARE THE LESSONS FROM THE FINANCIAL CRISIS ON USING MODERN FINANCE THEORY AS THE INTELLECTUAL FRAMEWORK FOR FINANCIAL REGULATION REFLECTED IN POST-CRISIS REGULATION? \\ Conor Duffin-Hall
}

\begin{abstract}
Modern finance theory informed the approach to financial regulation before the financial crisis. However, the crisis exposed the inadequacy of using modern finance theory as the intellectual framework for financial regulation, providing important lessons for future reform. Since the crisis, regulators and policymakers have been seeking to strengthen the financial system to avoid a repeat of 2008. Therefore, it is apposite to ask whether regulators and policymakers are simply taking the same, flawed pre-crisis approach and using modern finance theory as the basis for financial regulation, or whether there has been a fundamental pivot in their approach. This article examines how modern finance theory informed the precrisis regulatory approach, how doing so contributed to the failure of the financial system and examines two examples of post-crisis regulation to understand how, and whether, the lessons from the financial crisis are being incorporated into regulators' and policymakers' post-crisis approach to financial regulation.
\end{abstract}

\section{A. INTRODUCTION}

Modern finance theory - the efficient market hypothesis (EMH), in particular - heavily influenced the intellectual framework on which the pre-crisis regulatory approach was built. ${ }^{1}$ Modern finance theory refers to a group of theories in financial economics, which includes: modern portfolio theory, ${ }^{2}$ the capital asset pricing model, ${ }^{3}$ Modigliani and Miller's theorem on capital structure ${ }^{4}$ and the EMH. ${ }^{5}$ These theories are predicated on certain 'perfect-market' assumptions, such as the presence of rational market participants, perfect information and zero transaction costs. ${ }^{6}$ Modern finance theory suggests that rational market participants direct resources to their most effective use and that market prices are always accurate. ${ }^{7}$ The concurrent free market ideology resulted in

\footnotetext{
${ }^{*}$ LL.B. (Sheffield), LL.M. (UCL). I am thankful to Timothy Goyder, Andrew McLean and the editorial team at the UCL Journal of Law and Jurisprudence for their helpful comments on this article. All errors and omissions are my own.

${ }^{1}$ Dan Awrey, 'Complexity, Innovation and the Regulation of Modern Financial Markets' (2012) 2:2 Harv Bus L Rev 235, 237; FSA, 'The Turner Review: A Regulatory Response to the Global Banking Crisis' (2009) 39.

${ }^{2}$ Harry Markowitz, 'Portfolio Selection' (1952) 7(1) The Journal of Finance 77.

${ }^{3}$ William Sharpe, 'Capital Asset Prices: A Theory of Market Equilibrium under Conditions of Risk' (1964) 19(3) The Journal of Finance 425.

${ }^{4}$ Franco Modigliani and Merton Miller, 'The Cost of Capital, Corporation Finance and the Theory of Investment' (1958) 48(3) The American Economic Review 261.

${ }^{5}$ Eugene F Fama, 'Efficient Capital Markets: A Review of Theory and Empirical Work' (1970) 25 J Fin 383.

${ }^{6}$ Awrey, 'Complexity' (n 1$) 236$.

${ }^{7}$ FSA (n 1) 40.
} 
the deregulation of the financial markets from the 1970 s onwards ${ }^{8}$ as regulators placed their faith in the self-correcting powers of the market. ${ }^{9}$ This resulted in 'light regulation of commercial banks, even lighter regulation of investment banks and little, if any, regulation of the "shadow banking system", ${ }^{10}$ which comprises of financial institutions and off-balance sheet special purpose vehicles (SPVs) that perform traditional banking activities but are not subject to the same level of regulatory oversight, such as private equity funds and hedge funds. This 'light touch' approach to regulation led to an increasingly complex financial system as it enabled significant advances in financial innovation, notably in relation to securitisation in the 1980 s, which was thought to improve the allocative efficiency and stability of the financial system. ${ }^{11}$ However, as the former Chairman of the US Federal Reserve, Alan Greenspan, noted in the aftermath of global financial crisis (GFC): the 'whole intellectual edifice [on which regulation was built] collapsed... in the summer of [2007]'. ${ }^{12}$

The intellectual framework on which financial regulation is built should reflect how the markets operate in practice. Other theories, such as behavioural economics and Minsky's financial instability hypothesis, help explain certain phenomena that modern finance theory cannot account for, such as asset price bubbles. Because these theories help provide a more complete and accurate understanding of the financial system, they should be incorporated into the intellectual framework that informs the post-GFC regulatory approach. Conversely, as regulators and policymakers continue to reform financial regulation in response to the GFC, the danger is that they do so on the basis of the same flawed pre-crisis intellectual framework that was heavily informed by modern finance theory. ${ }^{13}$

The purpose of this article is to analyse whether the post-GFC regulatory approach reflects the dangers illustrated by the GFC of using modern finance theory as the intellectual framework for financial regulation. Part B outlines the most relevant part of modern finance theory for the purposes of this article, the EMH, and discusses how it informed the pre-crisis regulatory approach.

\footnotetext{
8 Matthew Sherman, 'A Short History of Financial Deregulation in the United States' [2009] CEPR <http://cepr.net/documents/publications/dereg-timeline-2009-07.pdf> accessed 15 August 2018.

${ }^{9}$ FSA (n 1) 87.

10 James Crotty, 'Structural Causes of the Global Financial Crisis: A Critical Assessment of the 'New Financial Architecture', (2009) 33 Camb J Econ 563, 564.

${ }^{11}$ FSA (n 1) 39.

12 Edmund L Andrews, 'Greenspan Concedes Error on Regulation' New York Times (New York, 23 October 2008) <https://www.nytimes.com/2008/10/24/business/economy/24panel.html> accessed 15 August 2018.

${ }_{13}$ Mads Tønnesson Andenæs and Iris HY Chiu, The Foundations and Future of Financial Regulation: Governance for Responsibility (Routledge 2014) 10.
} 
Specifically, Part B outlines the relationship between modern finance theory and the concepts of disclosure, market discipline and the microprudential approach; all of which formed a significant part of the pre-crisis regulatory approach. Part $\mathrm{C}$ analyses certain problems with the pre-crisis regulatory approach in light of the GFC. This part draws on behavioural economics to understand why supposedly rational market participants failed to impose market discipline and signal elevated risk in the financial system; the problem of conflating the EMH into a general statement of market efficiency; the financial instability hypothesis; the problems with the microprudential approach; and, the need for a more macroprudential approach. This discussion yields important lessons for post-crisis regulation. Thereafter, Part D evaluates post-crisis disclosure and investor protection regulation and the macroprudential measures introduced under Basel III to understand whether the aforementioned 'lessons' have been internalised by regulators and policymakers.

\section{B. MODERN FINANCE THEORY AND ITS INFLUENCE ON THE PRE-CRISIS REGULATORY APPROACH}

This section outlines the EMH, which provides necessary context for the remainder of the article. The EMH is the centrepiece of modern finance theory, ${ }^{14}$ and it has been blamed for causing, or at least contributing to, the financial crisis. ${ }^{15}$ This part then examines how modern finance theory influenced the pre-crisis regulatory approach.

\section{The Efficient Market Hypothesis}

According to the EMH, 'security prices fully reflect all available information'. ${ }^{16}$ An efficient market is one where 'there are large numbers of rational, profit-maximizers actively competing, with each trying to predict future market values of individual securities, and where important current information is almost freely available to all participants' ${ }^{17}$ Competition between these rational market participants results in price-relevant information being incorporated into security prices 'instantaneously' so that prices are a 'good estimate of their intrinsic value'. ${ }^{18}$ As Shleifer states, the EMH is underpinned by three progressively weaker assumptions. ${ }^{19}$ First, it is assumed

\footnotetext{
${ }^{14}$ Emilios Avgouleas, 'The Global Financial Crisis, Behavioural Finance and Financial Regulation: In Search of a New Orthodoxy’ (2009) 9 JCLS 23, 30.

${ }^{15}$ Ray Ball, 'The Global Financial Crisis and the Efficient Market Hypothesis: What Have We Learned?' (2009) 21 J Appl Corp Finance 8, 8.

${ }^{16}$ Eugene F Fama, 'Efficient Capital Markets: II' (1991) 46 J Fin 1575, 1575.

${ }^{17}$ Eugene F Fama, 'Random Walks in Stock Market Prices' (1965) 21 Fin An J 55, 56.

18 ibid.

${ }^{19}$ Andrei Shleifer, Inefficient Markets: An Introduction to Behavioral Finance (OUP 2000) 2.
} 
that investors are rational and rationally alter their expectations in response to new information. Second, if the first assumption does not hold, to the extent that some investors are irrational, their random errors will cancel each other out. Third, even if investors are irrational in similar ways, rational arbitrageurs will correct any mispricing. Therefore, asset prices should not deviate from their fundamental value, and only change due to the presence of new, price-relevant information.

Fama identified three forms of the EMH, which reflect different levels of information and can be used to understand the point at which the theory is no longer true. ${ }^{20}$ Weak-form market efficiency means that security prices incorporate all historical information. Therefore, investors cannot profit by analysing historical information about security prices or 'technical analysis'. Because security prices only move on the basis of new, price-relevant information, they follow a random walk; meaning, today's price movements are unrelated to those seen yesterday. ${ }^{21}$ The randomness arises because new information is, by definition, unpredictable. ${ }^{22}$ Empirical evidence supports the conclusion that stock prices follow random walks. ${ }^{23}$ Semi-strong-form market efficiency means that security prices incorporate and adjust immediately to all public information. Thus, an investor may only profit on private or 'inside' information. Consistent with semi-strong market efficiency, Keown and Pinkerton found that the share price of firms began to adjust upwards prior to the public announcement of an impending merger, before increasing and levelling out after the announcement. ${ }^{24}$ In other words, the security prices only fully adjusted when the announcement became public. Strong-form efficiency states that both public and private information is incorporated into security prices. This means that even with inside information, an investor cannot profit. However, this is contradicted by the Keown and Pinkerton study, because strong-form market efficiency would suggest that the price should have already fully incorporated the private information about the impending merger. This suggests that public disclosure of information performs an important function in maintaining an efficient market.

Gilson and Kraakman explain the mechanisms through which information is incorporated into security prices. ${ }^{25}$ First, information that is universally known will be incorporated into security

\footnotetext{
${ }^{20}$ Fama, 'Efficient Capital Markets' (n 5) 383.

${ }^{21}$ Fama, 'Random Walks' (n 17).

${ }^{22}$ Burton G Malkiel, 'The Efficient Market Hypothesis and Its Critics' (2003) 17 J Econ Persp 59, 59.

${ }^{23}$ Fama, 'Random Walks' (n 17).

${ }^{24}$ Arthur J Keown and John M Pinkerton, 'Merger Announcements and Insider Trading Activity: An Empirical Investigation' (1981) 36 The Journal of Finance 855.

${ }^{25}$ Ronald J Gilson and Reinier H Kraakman, 'The Mechanisms of Market Efficiency' (1984) 70 Va L Rev 549, 568588 .
} 
prices because it will inform all trades ('universally-informed trading'). ${ }^{26}$ Second, lesser-known, though still public, information informs the trading of professional traders ('professionallyinformed trading'). ${ }^{27}$ This group of traders invests considerable time and resources in finding and processing information. Whilst this group is relatively small, it is sufficient that it accounts for the critical volume of trading in the market in order for the information to be incorporated into the price. ${ }^{28}$ These trades then inform the third mechanism of market efficiency: 'derivatively informed trading', which takes the form of 'trade decoding' and 'price decoding'. ${ }^{29}$ The former involves traders observing and mimicking other trades, who hope to benefit from another party's superior information. The latter occurs when traders analyse, and trade on the basis of, price movements. ${ }^{30}$ Finally, Gilson and Kraakman argue that 'uninformed trading' can contribute to market efficiency. Uninformed trading is based on the conception of the 'naïve trader', who is not aware that the price indicates other traders' view of the available information and tries to forecast future events based on the information available to her. Whilst each trader will possess different information and different forecasts afflicted by their own constraints and biases, these will be offset by other traders' constraints and biases, thereby collectively producing a best-informed aggregate forecast. ${ }^{31}$ As will be discussed below, however, these mechanisms do not necessarily operate universally across different markets.

\section{How Modern Finance Theory Influenced the Pre-crisis Regulatory Approach}

The pre-crisis regulatory approach was 'light touch', with regulators and policymakers endorsing the view that markets are efficient and rational, as propagated by modern finance theory. ${ }^{32}$ This had a profound impact on the pre-crisis regulatory approach. As market participants were believed to be rational, there was a strong presumption in favour of deregulation and maximising market efficiency. ${ }^{33}$ Regulatory intervention was deemed unnecessary and seen to only increase transaction costs and lower the allocative efficiency of the market. ${ }^{34}$ We can observe this in relation to the over-the-counter (OTC) derivatives market. OTC derivatives are contracts, such as swaps,

\footnotetext{
26 ibid 568.

27 ibid 569.

${ }^{28}$ Fama, 'Efficient Capital Markets' (n 5) 388.

${ }^{29}$ Gilson and Kraakman (n 25) 573.

${ }^{30}$ Dan Awrey, 'The Mechanisms of Derivatives Market Efficiency’ (2016) 91:5 NYU L Rev 1104, 1117-1118.

${ }^{31}$ Gilson and Kraakman (n 25) 581.

${ }^{32}$ FSA (n 1) 39.

33 ibid 40.

${ }^{34}$ Emilios Avgouleas, Governance of Global Financial Markets: The Law, the Economics, the Politics (CUP 2012) 110.
} 
options or futures, traded outside an exchange or intermediary, the value of which is determined by reference to an underlying asset, such as stocks, bonds or currencies. Before the crisis, the OTC derivatives market 'remained... outside the perimeter of financial regulation in every major financial center'. ${ }^{35}$ Similarly, there was little regulation of financial products, on the assumption that market discipline would remove unnecessary or destructive products. ${ }^{36}$ The influence of modern finance theory on financial regulation can be seen in the following ways.

\section{a) Disclosure and the rational investor}

Modern finance theory informed regulators' and policymakers' understanding that markets consist of rational investors, who possess unlimited computational ability to process information, and make rational, wealth maximising decisions. This understanding had a profound impact on the rationale for disclosure regulation, as it was thought that providing an abundance of information to rational market participants would enable them to adjust their expectations and accurately price risk. ${ }^{37}$ Indeed, in theory, by providing this information through disclosure regulation, information costs - that is, the cost of obtaining and processing information - should be lowered, thereby improving market efficiency. ${ }^{38}$ Improving market efficiency, in turn, enables the self-regulation of the markets through market discipline, as discussed below. This rationale for disclosure, predicated on the rational investor, is manifest in pre-crisis regulation. For example, improving market efficiency was an explicit goal of the European Union (EU) Prospectus Directive and Transparency Directive. ${ }^{39}$ Similarly, in relation to retail investors, EU policymakers adopted an empowerment model and viewed the retail investor as a rational individual, who makes informed choices and exerts market discipline. Retail investors, as opposed to institutional investors, such as banks and other financial institutions, are non-professional individuals who buy and sell securities via investment platforms and brokers. Despite their lack of expertise, retail investors were granted access to the widest range of financial products and supplied with information to support their

\footnotetext{
35 Dan Awrey, 'The FSA, Integrated Regulation and the Curious Case of OTC Derivatives' (2010) 13 U Pa J Bus L 1,3 .

${ }^{36}$ FSA (n 1) 49.

${ }^{37}$ Emilios Avgouleas, 'The Global Financial Crisis and the Disclosure Paradigm in European Financial Regulation: The Case for Reform' (2009) 6 ECFR 440, 442.

${ }^{38}$ Gilson and Kraakman (n 25) 610.

${ }^{39}$ Directive (EC) 2003/71 on the Prospectus to be Published when Securities are Offered to the Public or Admitted to Trading [2003] OJ L 345/64 (Prospectus Directive), recitals 10 and 46; Directive 2004/109/EC of the European Parliament and of the Council of 15 December 2004 on the harmonisation of transparency requirements in relation to information about issuers whose securities are admitted to trading on a regulated market and amending Directive 2001/34/EC [2002] OJ L 390/38 (Transparency Directive), recital 1.
} 
decisions. ${ }^{40}$ However, there was little regard for the limitations of their ability to process complex information.

\section{b) Market Discipline}

It followed from the pre-crisis regulatory framework - informed by the view that markets are efficient and rational - that 'market discipline [could] be used as an effective tool in constraining harmful risk-taking'. ${ }^{41}$ Indeed, the theory of market discipline has long been a core principle of financial regulation and was relied upon extensively before the crisis. ${ }^{42}$ Market discipline is 'the mechanism via which market participants monitor and discipline excessive risk-taking behaviour by banks'. ${ }^{43}$ Bliss and Flannery explain that market discipline operates in two steps: monitoring and influence. ${ }^{44}$

Security holders and other market participants, such as deposit holders, monitor financial institutions' activities and risk-taking, and are incentivised to do so by the desire to be repaid. ${ }^{45}$ If a financial institution has issued securities that are publicly traded, then all known risk surrounding that institution can be inferred from its securities prices. ${ }^{46}$ The 'influence' element of market discipline is then exerted directly and indirectly. Direct market influence occurs when a firm changes its behaviour to avoid an adverse market response (ex ante market discipline) or in reaction to an adverse market response (ex post market discipline). Examples of adverse market responses include a fall in a firm's share price, or its creditors demanding greater yield or withholding finance. Indirect market influence occurs when the regulator intervenes in response to any such adverse market response. ${ }^{47}$ In other words, market participants are relied upon to monitor firms and signal issues, with the regulator using such signals to determine whether intervention is necessary. The reasoning behind such reliance on indirect market discipline is that

\footnotetext{
${ }^{40}$ Niamh Moloney, How to Protect Investors: Lessons from the EC and the UK (CUP 2010) 56-57.

${ }^{41}$ FSA (n 1) 39.

42 David Min, 'Understanding the Failures of Market Discipline' (2015) 92 Wash U L Rev 1421, 1423.

${ }^{43}$ Constantinos Stephanou, 'Rethinking Market Discipline In Banking: Lessons From The Financial Crisis' [2010] World Bank Policy Research Working Paper Series 52274.

${ }^{44}$ Robert Bliss, 'Market Discipline in Financial Markets: Theory, Evidence, and Obstacles' in Allen N Berger, Philip Molyneux and John OS Wilson (eds), The Oxford Handbook of Banking (2nd edn, OUP 2014) 569.

45 Robert Bliss and Mark Flannery, 'Market Discipline in the Governance of U.S. Bank Holding Companies: Monitoring vs. Influencing’ (2002) 6 European Finance Review 36, 362.

${ }^{46}$ Bliss (n 44) 569.

47 ibid.
} 
sophisticated market participants have greater resources and expertise than public regulators to monitor financial institutions' risk-taking activities. ${ }^{48}$

Market efficiency and rationality are fundamental to market discipline. Indeed, Min states that 'market discipline is best understood as a corollary of the $[\mathrm{EMH}]$, insofar as one of its core assumptions is that the pricing of banking liability reflects all publicly available information about the bank's risk' ${ }^{49}$ Certain assumptions must be satisfied for there to be effective market discipline: a sufficient number of market participants must have access to accurate and timely information; they need incentives to perform the monitoring function; they need to rationally adjust their expectations on the basis of new information; market prices need to reflect the risk profiles of financial institutions; and, managers of financial institutions need to alter their behaviour in response to market signals. ${ }^{50}$ The EMH and rational investor assumption, therefore, provide intellectual reinforcement for the belief that market participants will signal risk and exert market discipline. Additionally, relying on the $\mathrm{EMH}$, the theory of market discipline assumes that all market participants are homogenously sensitive to information and utilise information in the same way. ${ }^{51}$ This has important implications from a regulatory standpoint, as it suggests that all market participants will impose market discipline equally across different markets.

Market discipline was initially utilised by Basel II - the second of the Basel Accords, which provide recommendations on regulating the capital adequacy of banks. Under Basel II, market discipline formed the third pillar, alongside minimum capital requirements (the first pillar) and supervisory review (the second pillar). ${ }^{52}$ Whilst Basel II was not fully implemented in the EU or US during the build-up to the GFC, ${ }^{53}$ it was applied to the 19 largest US banks and, therefore, provides an insight into pre-crisis regulatory thinking. ${ }^{54}$ The third pillar mandated extensive disclosure requirements for, inter alia, banks' capital structure, capital adequacy, risk exposure, and credit, market and operational risk. The rationale was that 'market discipline imposes strong incentives on banks to conduct their business in a safe, sound and efficient manner, including an

\footnotetext{
48 David T Llewellyn, 'Inside The “Black Box” of Market Discipline' (2005) 25 Economic Affairs 41, 42.

${ }^{49}$ Min (n 42) 1433.

${ }^{50}$ Llewellyn (n 48) 43-44.

${ }^{51}$ Min (n 42) 1426.

52 BCBS, 'Basel II: International Convergence of Capital Measurement and Capital Standards' (2004).

${ }^{53}$ Jacques De Larosiére, 'The High-Level Group on Financial Supervision in the EU: Report' (2009) 16.

54 Darryl E Getter, 'US Implementation of the Basel Capital Regulatory Framework' (2012) 7-5700/R42744 Congressional Research Service 3 <https://fas.org/sgp/crs/misc/R42744.pdf> accessed 26 July 2018.
} 
incentive to maintain a strong capital base...' ${ }^{55}$ It was assumed that disclosure of a bank's capital structure and position would enable market participants to rein in excessive risk-taking by, for example, signalling dissatisfaction by discounting the bank's share price or withdrawing funds. Accordingly, Basel II conferred significant responsibility for managing the capital adequacy of banks to the market.

\section{c) The Microprudential Approach}

The pre-crisis regulatory belief that markets are self-correcting caused regulators and policymakers to focus on ensuring the safety and soundness of individual institutions, rather than the financial system as a whole. ${ }^{56}$ This reflects the microprudential approach to systemic risk, which was dominant prior to the GFC. ${ }^{57}$ Systemic risk is the risk that 'financial instability becomes so widespread that it impairs the functioning of a financial system to the point where economic growth and welfare suffer materially' ${ }^{58}$ In response, the microprudential approach seeks to ensure the safety of individual financial institutions on a stand-alone basis without regard to the relationships between financial institutions. It posits that 'the whole financial system is sound if and only if each institution is sound' ${ }^{59}$ This is based on a 'domino' conception of systemic crises, where the failure of one financial institution spreads to others through payment and settlement systems. ${ }^{60}$ Such a systemic crisis, according to the microprudential view, is initiated by an exogenous shock to individual financial institutions that occurs randomly. ${ }^{61}$ This exogenous view of systemic risk is, arguably, concurrent with the EMH. ${ }^{62}$ This is because if market prices accurately reflect all available relevant information and incorporate all known risk, then the cause of crises must be exogenous to the market. ${ }^{63}$ The failure of government policy may be such an exogenous shock. ${ }^{64}$ To address exogenous risk, the microprudential approach seeks to strengthen

\footnotetext{
55 BCBS, 'Working Paper on Pillar 3 - Market Discipline' (2001) 1.

${ }^{56}$ FSA (n 1) 87.

${ }^{57}$ Rizwaan J Mokal, 'Liquidity, Systemic Risk, and the Bankruptcy Treatment of Financial Contracts' 10 Brook J Corp Fin \& Com L 15, 21.

${ }^{58}$ European Central Bank, 'The Concept of Systemic Risk’ [2009] Financial Stability Review 134, 134.

${ }^{59}$ Mokal (n 57) 21; Claudio Borio, 'Rediscovering the Macroeconomic Roots of Financial Stability Policy: Journey, Challenges, and a Way Forward' (2011) 3 Ann Rev Fin Econ 87, 88.

${ }^{60}$ Mokal (n 57) 21.

${ }^{61}$ Markus K Brunnermeier and others (eds), The Fundamental Principles of Financial Regulation (ICMB 2009) xvi; Mokal (n 57) 21.

${ }^{62}$ Shaun Breslin, East Asia and the Global Crisis (Routledge 2013) 19.

${ }^{63}$ Jay Cullen, Executive Compensation in Imperfect Financial Markets (Edward Elgar 2014) 90.

${ }^{64}$ John Cassidy, 'Interview with Eugene Fama' The New Yorker (13 January 2010) <https://www.newyorker.com/ news/john-cassidy/interview-with-eugene-fama> accessed 15 August 2018.
} 
individual financial institutions. In contrast, the macroprudential approach views systemic risk as endogenous to the financial system and seeks to protect the system as a whole. As set out below, this approach was largely neglected prior to the crisis.

The capital adequacy measures adopted under Basel II were exclusively microprudential in nature. Capital adequacy has been described as the 'mainstay' of microprudential regulation. ${ }^{65}$ Indeed, the rationale behind capital adequacy is that 'ensuring the solvency of individual institutions ensures the soundness of the financial system as a whole'. ${ }^{66}$ Under Basel II, banks were - and still are under Basel III - required to hold 8 per cent of their total risk-weighted assets (RWAs), as established by Basel I. ${ }^{67}$ RWAs refers to the amount of a bank's assets after being adjusted for risk, which involves assessing credit, market and operational risk. Basel II introduced three approaches to calculating the capital requirements for credit risk. ${ }^{68}$ First, the standardised approach prescribes risk-weights to different asset types, relying on credit ratings to calculate the risk attached to the assets. Second, the foundation internal ratings-based (IRB) approach allows banks to use their internal models to calculate the probability of default only. Third, the advanced IRB approach allows sophisticated banks to calculate the probability of default, loss at default and exposure to default. Similarly, Basel II allowed sophisticated banks to use their own models to calculate market risk ${ }^{69}$ and operational risk. ${ }^{70}$ This devolved approach was then supplemented by supervisory oversight (pillar two) and disclosure to the market to enable market discipline (pillar three).

It is evident from the above that Basel II conferred significant responsibility to sophisticated banks to determine their own capital adequacy requirements. This devolution of responsibility for capital adequacy to the same institutions subject to the requirements emanated from pre-crisis 'market fundamentalism'71 and the concurrent view that banks were best placed to manage their own institutional risk. ${ }^{72}$ However, banks took advantage, tweaking their assets and

\footnotetext{
65 Andenæs and Chiu (n 13) 335.

${ }^{66}$ Brunnermeier and others (n 61) 14.

${ }^{67}$ BCBS, 'Basel II' (n 52) 2.

${ }^{68}$ Andenæs and Chiu (n 13) 293.

69 BCBS, 'Amendment to the Capital Accord to Incorporate Market Risks' <https://www.bis.org/publ/bcbs24.pdf> accessed 21 August 2018.

${ }^{70}$ BCBS, 'Basel II' (n 52) 137.

71 Awrey, 'Complexity' (n 1) 237-238.

72 Andenæs and Chiu (n 13) 293; FSA (n 1) 87.
} 
models in order to reduce their capital adequacy costs and increase their leverage. ${ }^{73}$ The complexity of these models undermined the ability of market participants to understand them. Additionally, these internal models rely on value-at-risk and related methodologies, which, it has been argued, are 'insufficient' for capital adequacy purposes, because, among other problems, they fail to account for endogenous risk and so produce inaccurate risk forecasts and promote systemic crises. $^{74}$ These problems were ignored, yet were manifestly present in the crisis, as discussed below.

\section{PROBLEMS WITH THE PRE-CRISIS REGULATORY APPROACH}

The above discussion demonstrates the pervasive influence modern finance theory had on the precrisis regulatory approach. At the heart of this approach was the view that markets are efficient and rational and, therefore, able to regulate themselves. This part examines the flaws in the precrisis approach. It first provides an overview of the events of the GFC. Then it undertakes a behavioural critique of the failure of supposedly rational market participants to exert market discipline before the crisis. Thereafter, it discusses the problem of conflating the EMH into a general statement of market efficiency and how this may have also undermined market discipline. Part $\mathrm{C}$ then discusses the problems with the microprudential approach and draws on Hyman Minsky's financial instability hypothesis to demonstrate the need for a more macroprudential approach. This discussion yields important lessons for future regulatory developments; some of which are examined in relation to post-GFC regulation in Part D.

\section{An Overview of the Financial Crisis}

The US housing market bubble, which precipitated the crisis, was fuelled by an expansion of credit and subprime mortgage lending. These mortgages were then packaged into mortgage-backed securities (MBSs) and often repackaged with other forms of debt to create collateralised debt obligations (CDOs) through a process called 'securitisation'. ${ }^{75}$ Securitisation converts the cash flow from a relatively illiquid asset, such as a mortgage, into liquid securities sold on the financial

\footnotetext{
${ }^{73}$ Giuseppe Mastromatteo and Lorenzo Esposito, 'Minsky at Basel: A Global Cap to Build an Effective Postcrisis Banking Supervision Framework' [2016] Levy Economics Institute of Bard College Working Paper 875 23; Tom Braithwaite, 'Banks Turn to Financial Alchemy in Search for Capital' Financial Times (London, 24 October 2011) <https://www.ft.com/content/50a674b8-fe41-11e0-a1eb-00144feabdc0> accessed 22 August 2018.

${ }^{74}$ Jón Daníelsson and others, 'An Academic Response to Basel II' Special Paper 130 Financial Markets Group Special Paper Series 17, 4.

75 Steven Schwarcz, 'Regulating Complexity in Financial Markets’ (2009) 87 Wash U L Rev 211, 220.
} 
markets, such as a mortgage-backed bond (a form of MBS). The cash flow from the securitised assets then repays the issued debt security; for instance, the mortgage repayments are used to pay interest to the holders of mortgage-backed bonds. These securities are divided into tranches, each with different levels of risk, and therefore return, that reflect the repayment priority of the tranche. Before the crisis, the riskier tranches proved more difficult to sell and were 're-securitised' into CDOs, alongside other forms of debt. ${ }^{76}$ These securities were issued through off-balance sheet vehicles, which held the underlying assets, thereby allowing banks to remove mortgages from their balance sheets and increase their leverage. ${ }^{77}$ Despite their content, MBS and CDOs received AAAratings from credit rating agencies, and demand for these securities was significant, with Wall Street issuing around \$700bn in CDOs between 2003 and 2007. ${ }^{78}$ This demand contributed to lower lending standards and a greater number of mortgages being granted, which further fuelled the housing bubble. ${ }^{79}$ Many financial institutions then purchased credit default swaps (CDSs) to act as an insurance policy against the default of the MBS and CDOs from institutions such as $\mathrm{AIG},{ }^{80}$ which increased the interconnectedness of the financial system and its exposure to US subprime mortgages. ${ }^{81}$ However, when the US housing market slowed in 2006, it caused mortgagors to default, which led to the value of mortgage-related securities to decrease significantly. ${ }^{82}$ By July 2007, two Bear Stearns' hedge funds, which were primarily invested in mortgage-related securities, failed, despite an earlier bailout. ${ }^{83}$ This was followed by the failure of Lehman Brothers and bail-out of AIG in September 2008. ${ }^{84}$

\section{The Breakdown of Market Discipline}

\footnotetext{
76 The Financial Crisis Inquiry Commission, The Financial Crisis Inquiry Report: Final Report of the National Commission on the Causes of the Financial and Economic Crisis in the United States (US Government Printing Office 2011) 130.

${ }^{77}$ FSA (n 1) 20.

78 The Financial Crisis Inquiry Commission (n 76) 129.

79 Patrick Jenkins, 'A Decade on from the Financial Crisis, What Have We Learnt?' Financial Times (London, 31 August 2017) <https://www.ft.com/content/543359aa-8d0d-11e7-a352-e46f43c5825d> accessed 17 August 2018.

${ }^{80}$ Crotty (n 10) 573.

${ }^{81}$ Avgouleas, Governance of Global Financial Markets (n 34) 103-104.

${ }^{82}$ Cullen (n 63) 125.

83 Jeff Pruzan, 'Timeline: Bear Stearns' Year of Turmoil' Financial Times (London, 14 March 2008) <https://www.ft.com/content/d7936764-f1d5-11dc-9b45-0000779fd2ac> accessed 17 August 2018.

${ }^{84}$ Francesco Guerrera and Krishna Guha, 'Wall Street Crisis Hit Stocks' Financial Times (London, 15 September 2008) <https://www.ft.com/content/f8834910-82aa-11dd-a019-000077b07658> accessed 8 September 2019; Francesco Guerrera, Aline van Duyn and Krishna Guha, 'US to Take Control of AIG' Financial Times (London, 17 September 2008) <https://www.ft.com/content/271257f2-83f1-11dd-bf00-000077b07658> accessed 8 September 2019.
} 
Although US house prices were, in fact, declining and the number of mortgage defaults had increased in 2005 and $2006,{ }^{85}$ market prices only reflected the heightened risk in the financial system in July 2007 after the credit rating agencies downgraded the ratings attached to subprimerelated securities. ${ }^{86}$ Therefore, in the build-up to the crisis, market participants did not signal the elevated risk in the financial system and impose market discipline as one would expect. These facts led the Turner Review, on the regulatory response to the financial crisis, to conclude that 'market discipline expressed via market prices cannot be expected to play a major role in constraining bank risk taking'. ${ }^{87}$ One might attribute this failure to moral hazard, created by an implicit 'guarantee' of a bailout for certain institutions which were 'too big to fail', which removed any incentive to monitor financial institutions or rein in risk-taking. However, financial crises and bubbles pre-date the 'too big to fail' problem, and any guarantee was not so certain or clearly defined to inspire the level of confidence required to explain the prolonged absence of market discipline. ${ }^{88}$ Accordingly, the next sub-part undertakes a behavioural critique of disclosure-based market discipline, which challenges the EMH and offers an explanation for apparent absence of market discipline in the build-up to the crisis.

\section{a) A Behavioural Critique}

Based on the view that market participants are rational, the failure of market discipline can be attributed to inadequate disclosure. ${ }^{89}$ The inadequate disclosure argument posits that market participants did not have sufficient information to enable comprehensive risk assessment. ${ }^{90}$ However, as outlined above, the housing market was evidently in decline, and disclosure requirements mandated under securities regulation produced lengthy prospectuses for MBS and CDOs. ${ }^{91}$ The problem was that these securities were beyond the comprehension of most market participants, ${ }^{92}$ with many purchasing them based on the AAA-rating without reading the

\footnotetext{
${ }^{85}$ John Krainer and Elizabeth Laderman, 'Prepayment and Delinquency in the Mortgage Crisis Period' Working Paper 2011-25 Federal Reserve Bank of San Francisco 6.

${ }^{86}$ Min (n 42) 1466, 1492; Stephanou (n 43) 9; FSA (n 1$) 46$.

${ }^{87}$ FSA (n 1) 47.

${ }^{88}$ Bliss (n 44) 583; Min (n 42) 1472-3.

${ }^{89}$ Avgouleas, 'The Global Financial Crisis and the Disclosure Paradigm' (n 37) 444.

${ }^{90}$ The President's Working Group on Financial Markets, 'Policy Statement on Financial Market Developments' (2008) 3.

${ }^{91}$ Schwarcz, 'Regulating Complexity' (n 75) 222.

${ }^{92}$ Steven Schwarcz, 'Protecting Financial Markets: Lessons from the Subprime Mortgage Meltdown' (2007) 93 Minnesota L Rev 373, 383.
} 
prospectus. ${ }^{93}$ This suggests that market participants do not - or cannot - always utilise information as the EMH would predict. But whilst orthodox theory cannot explain why market participants failed to process or respond to the available information, behavioural economics can. Behavioural economics posits that, contrary to the rational investor model, market participants are boundedly rational and possess 'limited computational skills and seriously flawed memories'. ${ }^{94}$ Therefore, the stronger argument is that complexity undermined the utility of disclosure, and this complexity precipitated complacency. ${ }^{95}$ In turn, this complacency, in the form of over-reliance on heuristics and herding, ${ }^{96}$ may explain why market participants ignored the apparent warnings signs, such as the declining housing market, and failed to signal the build-up of risk that led to the financial crisis. Therefore, even if all information was disclosed, it would have necessarily been undermined by complexity.

Tversky and Kahneman explain that, when faced with complexity, boundedly rational market participants employ heuristics which 'reduce the complex tasks of assessing probabilities and predicting values to simpler judgmental operations $\cdot{ }^{97}$ Examples of heuristics include financial models, such as value-at-risk ( $\mathrm{VaR}$ ) and credit ratings. Reliance on such heuristics is necessary, and to a certain extent rational, in modern finance due to the complexity involved..$^{98}$ But there were two problems with the pre-crisis reliance on heuristics. First, the heuristics relied upon in the buildup to the crisis had become detached from reality and were inaccurate, particularly as financial markets had become increasingly complex and market participants did not question or re-evaluate their accuracy since their inception. ${ }^{99}$ Second, market participants over-relied on these flawed heuristics. ${ }^{100}$ Indeed, as outlined, it was normal for market participants to purchase complex securities based on their AAA-rating without undertaking any thorough due diligence. ${ }^{101}$ Faith in the accuracy of credit ratings was built on a long history of reliability in relation to relatively

\footnotetext{
${ }^{93}$ Steven Schwarcz, 'Disclosure's Failure in the Subprime Mortgage Crisis' (2008) 3 Utah L Rev $1109,1110$.

${ }^{94}$ Cass R Sunstein, Christine Jolls and Richard H Thaler, 'A Behavioral Approach to Law and Economics' (1998) 50 Stan L Rev 1471, 1477.

95 Schwarcz, 'Disclosure's Failure' (n 93).

${ }^{96}$ Steven Schwarcz, 'Regulating Complacency: Human Limitations and Legal Efficacy’ (2018) 93 Notre Dame L Rev 1073.

97 Amos Tversky and Daniel Kahneman, ‘Judgment under Uncertainty: Heuristics and Biases' (1974) 185 Science $1124,1124$.

98 Schwarcz, 'Regulating Complacency' (n 96) 1081.

99 Steven Schwarcz and Lucy Chang, 'The Custom-to-Failure Cycle' (2012) 62 Duke L J 29, 773.

100 Schwarcz, 'Disclosure's Failure' (n 93) 1115.

101 ibid 1114.
} 
simple debt securities, but the accuracy of these ratings diminished as they were applied to more complex MBS and CDOs. ${ }^{102}$ Market participants also over-relied on VaR - a risk-management tool that provides a figure representing the maximum loss a portfolio can incur over a specified time period and confidence level, which showed the risk of default attached to mortgage-related securities to be low. ${ }^{103}$ This is because, amongst other problems, the VaR models used were based on short-term historical data - that is, the pre-crisis market upturn when loan defaults were low and so showed the risk of default to be minimal. ${ }^{104}$

Herding, defined as 'behaviour patterns that are correlated across individuals', ${ }^{105}$ further explains why market participants did not utilise the available information and signal the increased risk in the financial system before the crisis. ${ }^{106}$ In this respect, herd behaviour also challenges the perfect-market assumption that market participants will adjust their expectations on the basis of all available information. Herding itself may be rational if an investor assumes that another investor has better information. However, this may lead to an 'information cascade' where the herd follows incorrect information without question, limiting the utility of disclosure. ${ }^{107}$ An irrational herd comprising of individually rational market participants may then cause assets to become overvalued. ${ }^{108}$ The pre-crisis euphoria over MBS and CDOs is an example. Herding models also reveal that employees with low-ability sometimes mimic their peers to avoid exposing themselves and harming their reputation. ${ }^{109}$ Further, even employees or managers who believe the market is over-valued may follow the herd for job safety, or shift from low-to-high-risk strategies to avoid being outperformed by peers. ${ }^{110}$ Similarly, managers may have purchased MBS and CDOs on the basis of their low VaR, despite being aware of the significant potential losses, as they knew most other firms were also investing in the same instruments. ${ }^{111}$ Accordingly, herd behaviour also challenges the EMH's postulation that arbitrageurs will correct any mispricing. This is because

\footnotetext{
102 Schwarcz and Chang (n 99) 774.

${ }^{103}$ Schwarcz, 'Regulating Complacency' (n 96) 1086.

${ }^{104}$ Crotty (n 10) 571.

105 Andrea Devenow and Ivo Welch, 'Rational Herding in Financial Economics' (1996) 40 European Economic Review 603, 604.

${ }^{106}$ Avgouleas, 'The Global Financial Crisis, Behavioural Finance and Financial Regulation' (n 14) 33.

107 Schwarcz, 'Regulating Complacency' (n 96) 1078.

108 Cullen (n 63) 75.

109 Devenow and Welch (n 105) 608.

${ }^{110}$ Paul M Healy and Krishna G Palepu, ‘The Fall of Enron' (2013) 17 J Econ Persp 3, 19.

111 Steven Schwarcz, 'Conflicts and Financial Collapse: The Problem of Secondary-Management Agency Costs' (2009) 26 Yale Journal on Regulation 14, 460.
} 
market participants who adopt a contrarian position in order to benefit from arbitrage by, for instance, short selling incur significant transaction costs to maintain their short position whilst market prices are increasing and may become insolvent before any profit is realised. Therefore, deciding to join the herd and 'ride the bubble' to realise short-term gains may be the rational option, thereby exacerbating mispricing. ${ }^{112}$

It is evident that behavioural economics poses a challenge to the $\mathrm{EMH}$ and its continued role in financial regulation. Post-GFC regulatory developments should incorporate the lessons from behavioural economics, which are particularly relevant for disclosure regulation. It also has implications on the extent to which market participants can be relied upon to discipline financial institutions and signal risk, therefore justifying greater regulatory oversight. However, the utility of behavioural economics for regulatory purposes is limited, because 'behavioural theories... are so tentative' and do not provide us with a complete understanding of human behaviour. ${ }^{113}$ Further, human behaviour is inconsistent and not all market participants will necessarily respond in an irrational, or consistently irrational, manner to any particular set of circumstances. ${ }^{114}$ Accordingly, whilst useful in understanding market participants' behaviour, behavioural economics is not itself adequate to completely replace the EMH in informing the regulatory approach, but it does demonstrate the limits of the extent to which the EMH can be relied upon for regulatory purposes. ${ }^{115}$ The danger is that regulators will overcompensate and presume all market participants are irrational, leading to an overly paternalistic regulatory regime.

\section{b) The Conflation of (Stock) Market Efficiency}

The EMH is, fundamentally, a theory about stock markets. Stock markets comprise of many participants whose trades are relatively low in value. These market participants, like the securities they trade in, are highly information-sensitive, and there is a constant flow of new information into the market. ${ }^{116}$ These features of the stock market play an important role in the mechanisms of market efficiency espoused by Gilson and Kraakman, as outlined above.

\footnotetext{
112 Donald C Langevoort, 'Taming the Animal Spirits of the Stock Markets: A Behavioral Approach to Securities Regulation’ (2002) 97 Nw U L Rev 135, 148.

113 ibid 138.

${ }^{114}$ Sunstein, Jolls and Thaler (n 94) 1471.

115 Cullen (n 63) 86.

116 Bengt Holmstrom, 'Understanding the Role of Debt in the Financial System' [2015] BIS Working Papers No 479 $6-7$.
} 
However, the pre-crisis 'equity-centric view' of market efficiency became conflated and transformed into a 'more general... statement about the efficiency of financial markets', potentially contributing to the pre-crisis presumption in favour of deregulation. ${ }^{117}$ Conversely, the way in which market participants utilise information necessarily varies according to the structure of the market and the nature of the security being traded. Awrey, for example, demonstrates that the mechanisms of derivatives market efficiency are different to those in stock markets, as a result of the differences between the two markets; for instance, historically, there has been no public dissemination of prices and other information for derivatives, as there is in stock markets. ${ }^{118}$ Accordingly, imposing disclosure and transparency requirements across all markets, on the assumption market efficiency operates in the same way, may not have the intended effect.

Before the crisis, the issue of conflating stock market efficiency was apparent in relation to market discipline. Indeed, Min attributes the failure of market discipline in the build-up to the GFC to the fact that it was assumed that all investors are homogenously risk sensitive, and investors in money market instruments were over-relied upon to exert market discipline. ${ }^{119}$ It was thought that a significant amount of market discipline would be exerted by investors in money market instruments as a result of their sheer volume. ${ }^{120}$ However, stock markets and money markets are built on 'two different entirely... diametrically opposite logics'. ${ }^{121}$ Money market instruments are debt claims that have short maturities (less than one year), such as treasury bills, commercial paper and deposits, and are seen as cash equivalents. Further, in contrast to equity, money market instruments are informationally insensitive by design to avoid the adverse selection problem, which improves liquidity and avoids the need to conduct due diligence. ${ }^{122}$ If the parties are confident there is sufficient collateral, detailed information regarding the instrument is unnecessary. ${ }^{123}$ Therefore, money markets do not conform to the EMH, because investors in money market instruments are not as highly risk sensitive as investors in the stock market and prices do not reflect large amounts of information. ${ }^{124}$ Instead, they become informationally

\footnotetext{
${ }^{117}$ Awrey, 'Derivatives Market Efficiency' (n 30) 1106.

118 Awrey, 'Derivatives Market Efficiency' (n 30).

${ }^{119}$ Min (n 42) 1469.

120 ibid 1479.

${ }^{121}$ Holmstrom (n 116) 5.

${ }^{122}$ Gary B Gorton, 'Slapped in the Face by the Invisible Hand: Banking and the Panic of 2007' [2009] SSRN Electronic Journal 7 <http://www.ssrn.com/abstract=1401882> accessed 8 August 2018.

${ }^{123}$ Holmstrom (n 116) 5.

124 Gorton (n 122) 10.
} 
sensitive upon a systemic shock, which creates uncertainty as to which depositor (that is, bank or shadow bank) is at risk, causing investors to stop refinancing all money market instruments, and liquidity to evaporate. ${ }^{125}$

We can observe the aforementioned shift in informational sensitivity in the GFC in July 2007. Following the downgrade in the ratings of subprime-related securities, the money markets froze, and financial institutions stopped buying MBS and CDOs. This caused credit to dry up and institutions that were heavily exposed to money market instruments, such as Bear Sterns, to fail and market discipline to be restored. ${ }^{126}$ However, whilst this explanation for the failure of market discipline somewhat contradicts the earlier behavioural critique, it seems both explanations may have played a role in the GFC. In other words, a combination of factors may have been present. Some market participants may have been insensitive to risk due to the nature of their investments, whilst others herded and over-relied on heuristics. Nevertheless, the conflation of market efficiency has consequences as to the extent to which increased transparency and disclosure requirements can be relied upon to improve the safety of the financial system, as well as the reliability of market discipline.

\section{Whither the Microprudential Approach?}

Before the crisis, a firmly microprudential approach to financial regulation was adopted, which is exemplified by the capital adequacy requirements under Basel II. Thus, on the view that risk is exogenous to the system, as supported by the EMH, regulators sought to strengthen individual financial institutions. However, in light of the GFC, and as this sub-part discusses, a purely microprudential approach is inadequate. This sub-part first considers the financial instability hypothesis (FIH), which, unlike the EMH, explains the endogenous instability of the financial system and how it tends towards crises. ${ }^{127}$ Then the problems with the microprudential approach are examined. This sub-part concludes by setting out why the macroprudential approach is more suitable for regulatory purposes, though it is not a panacea.

a) The Financial Instability Hypothesis

\footnotetext{
${ }^{125}$ Holmstrom (n 116) 15.

${ }^{126}$ Min (n 42) 1492.

${ }^{127}$ Hyman P Minsky, Stabilizing an Unstable Economy (McGraw-Hill 2008) 11.
} 
The financial instability hypothesis (FIH) is a 'theory of the impact of debt on systemic behaviour and also incorporates the manner in which debt is validated' ${ }^{128}$ The FIH, essentially, presents the financial system as being procyclical and crises as endogenous to the financial system, thus challenging the EMH. Procyclicality 'refers to the dynamic interactions (positive feedback mechanisms) between the financial and the real sectors of the economy'. ${ }^{129}$ The FIH is not inconsistent with the earlier discussion on behavioural economics, because a 'central tenet' of the FIH is that as memory of the previous crisis fades, behaviour changes to reduce the financial system's resilience. ${ }^{130}$ Therefore, whilst behavioural economics explains individual market participants' behaviour, the FIH is broader and explains how such behaviour alters the structure of the financial system over time.

Minsky identified three types of finance units, which can include financial institutions, individual investors, and households. Hedge finance units have sufficient cash flow to meet their payment obligations in full. Speculative finance units can repay the interest but must refinance the principal. These units have to roll over on their liabilities by, for example, issuing new debt to meet maturing commitments. ${ }^{131}$ In contrast, Ponzi finance units cannot repay neither the principal nor interest payments with their cash flow, and must borrow or sell assets in order to remain solvent. The FIH states that, over protracted periods of 'good times', the structure of the financial system shifts from being dominated by hedge finance units to being dominated by speculative and Ponzi finance units. ${ }^{132}$ This shift occurs because market participants become increasingly confident, as asset prices increase, and prior practices are validated. The financial system then becomes euphoric and increasingly leveraged, which drives asset prices upwards. As speculative and Ponzi units become more common as the cycle progresses, the financial system becomes more debt-laden and vulnerable to asset price devaluations or interest rate rises, which causes speculative units to become Ponzi units and Ponzi units to disappear. ${ }^{133}$ This is because units with cash flow shortages seek to deleverage and sell assets, which results in a sudden collapse in asset

\footnotetext{
128 Hyman P Minsky, 'The Financial Instability Hypothesis' [1992] Levy Economics Institute of Bard College Working Paper 746.

${ }^{129}$ Financial Stability Forum, 'Report of the Financial Stability Forum on Addressing Procyclicality in the Financial System' (2009) 8.

${ }^{130}$ Benjamin Friedman, David Laibson and Hyman P Minsky, 'Economic Implications of Extraordinary Movements in Stock Prices’ (1989) 1989 Brookings Papers on Economic Activity 137, 139.

${ }^{131}$ Minsky (n 128) 7.

132 ibid 8.

133 ibid.
} 
prices and the supply of credit to disappear. This has become known as a 'Minsky moment' ${ }^{134}$ The cycle then repeats, with a shift back towards a system dominated by hedge finance units.

The FIH is somewhat exemplified by the GFC. Indeed, McCulley argues that increasingly risky lending practices in the subprime mortgage market illustrate Minsky's instability cycle - that is, there was a shift from granting traditional interest plus principal mortgages (the hedge finance unit), towards interest only mortgages dependent on house prices continuing to increase (the speculative finance unit) and finally 'negative amortisation' mortgages that allowed borrowers to add unpaid monthly repayments to the principal loan (the Ponzi finance unit). ${ }^{135}$ This was, as has been outlined, fuelled by the euphoria over MBS and CDOs, with investors and financial institutions becoming increasingly leveraged, herding towards mortgage-related securities and fuelling asset price bubbles. In some respects, financial institutions themselves became speculative and Ponzi finance units, as they became overleveraged and dependent on short-term refinancing arrangements. We can observe this in relation to Northern Rock, which was 'heavily dependent on short-term wholesale market finance and issuing securities to fund mortgages, rather than retail deposits, leading it to have a leverage-to-deposit ratio of 322 per cent'. ${ }^{136}$ And when the 'Minsky moment' arrived, Northern Rock was unable to roll over its short-term funding and collapsed. Therefore, the FIH provides a framework to understand the GFC and the endogeneity of risk to the financial system. Regulators and policymakers should, accordingly, incorporate the FIH into the post-GFC regulatory approach.

\section{b) The Flaws in the Microprudential Approach}

As outlined, an exclusively microprudential approach was adopted before the crisis, and regulators sought to strengthen individual financial institutions in order to protect them against systemic risk. However, this approach, as the GFC demonstrates, was flawed for a number of reasons.

First, market discipline cannot be relied upon to rein in institutional risk taking in the 'boom' periods. Second, the pre-crisis microprudential approach suffered from a fallacy of composition - that is, it assumed strengthening individual financial institutions would improve the

\footnotetext{
134 ibid.

135 Paul McCulley, 'The Shadow Banking System and Hyman Minsky's Journey' Pimco (May 2009) <https://www.cfainstitute.org/-/media/documents/book/rf-publication/2009/rf-v2009-n5-15.ashx> accessed 28 September 2019.

${ }^{136}$ Emma Dunkley, 'Ten Years after Northern Rock: Has UK Banking Changed?' Financial Times (London, 13 September 2017) <https://www.ft.com/content/d05c3ea4-97bf-11e7-a652-cde3f882dd7b> accessed 16 August 2018.
} 
safety of the whole system. ${ }^{137}$ Conversely, if each institution decides to deleverage at the same time in order to make themselves safer, then their collective actions will cause asset prices to spiral downwards and destabilise the financial system. ${ }^{138}$ This fallacy stems from the fact the microprudential approach views risk as exogenous to the system. ${ }^{139}$ Third, as the FIH explains, risk is endogenous to the financial system.

These flaws undermined the measures adopted under Basel II, which, as discussed, was predicated on the microprudential approach. Notably, Basel II did not include requirements that limited the leverage of financial institutions or considered liquidity potential problems. Both issues were present in the GFC. ${ }^{140}$ Furthermore, Basel II increased procyclicality. For example, if credit ratings are used to measure risk for the purposes of RWAs, as under the 'standardised approach' to credit risk under Basel II, they are susceptible to the credit cycle. This cycle means that during the 'boom' period the risks surrounding borrowers and creditors appear to be low, so financial institutions are 'under-charged'. Conversely, during the 'bust' period, financial institutions are required to hold more capital against their assets as the risk of default increases, which causes them to scale back lending. ${ }^{141}$ The adoption of VaR under Basel II, as used by sophisticated financial institutions to calculate their capital charges, also increased procyclicality. This is because VaR viewed risk as exogenous and ignored the actions of other market participants. However, in a downturn, if market participants use similar VaR models, their actions will reinforce each other's. Thus, a downturn in market prices can cause a self-reinforcing sell-off of assets. ${ }^{142}$ Accordingly, due to the flaws in Basel II, financial institutions were undercapitalised in the GFC, though Basel III has sought to address these flaws, as discussed below.

\section{c) The Need for a More Macroprudential Approach}

As stated, the macroprudential approach views risk as endogenous and seeks to protect the financial system as a whole, rather than individual institutions. This approach, therefore, recognises the fallacy of composition that plagued the pre-crisis microprudential approach and Basel II. Consistent with the FIH, the macroprudential approach addresses the two aspects of systemic risk: procyclicality and build-up of risk over time (the 'time dimension') and issues

\footnotetext{
${ }^{137}$ Mokal (n 57) 21.

138 Brunnermeier and others (n 61) 15.

${ }^{139}$ Borio (n 59) 89.

${ }^{140}$ Avgouleas, Governance of Global Financial Markets (n 34) 133.

${ }^{141}$ John Armour and others, Principles of Financial Regulation (OUP 2016) 415.

${ }^{142}$ Daníelsson and others (n 74) 6.
} 
arising from inter-connectedness and interlinkages in the financial system (the "cross-sectional dimension'). ${ }^{143}$ Macroprudential measures address the time dimension of systemic risk by seeking to limit the build-up of risk during the 'boom' phase, whilst also limiting the costs of financial distress in the 'bust' phase. ${ }^{144}$ Examples of such measures include countercyclical buffers and leverage ratios, as discussed below. Macroprudential measures address the 'cross-sectional dimension' of systemic risk by reducing the concentration of risk that can arise from financial institutions being similarly exposed (for instance, to certain assets, liabilities or services) or interlinked (for instance, by counterparty risk). ${ }^{145}$ Such exposures and interlinkages were ignored by pre-crisis microprudentialism but were manifest in the GFC, as most financial institutions became exposed to the US housing market through MBS and CDOs and interconnected via CDSs. This cross-sectional risk was amplified by complexity and uncertainty, which arose from the complex securities being traded and opacity of the financial system. Examples of macroprudential measures include using central counterparties for OTC transactions, which insulates parties from their counterparty's default, or requiring certain securities be traded on organised trading venues to increase transparency and the availability of information. ${ }^{146}$ However, the latter may conflict with the above discussion on the limits of disclosure and heterogeneity of markets, and disclosure-based regulation may not have the same intended effect across different markets.

The macroprudential approach is preferable, because it addresses the inherent instability of the financial system, as postulated by the FIH - a fact ignored by modern finance theory and the microprudential approach. But it does not follow that microprudential tools, such as capital adequacy requirements, should be abandoned altogether, as strengthening individual financial institutions may improve the safety of the whole financial system. Further, the macroprudential tools that may be deployed to curb credit bubbles are afflicted with a timing problem - that is, it is difficult to assess whether the financial markets are experiencing a boom or simply growing. ${ }^{147}$ Regulators may also be swept up in the market's irrational exuberance or subject to political pressure or lobbying by market participants to allow the credit bubble to continue, stunting the effectiveness of any countercyclical measures. Additionally, macroprudential measures that seek

\footnotetext{
143 Borio (n 59) 94.

${ }^{144}$ Financial Stability Forum (n 129) 10.

${ }^{145}$ FSB, IMF and BIS, 'Macroprudential Policy Tools and Frameworks: Update to G20 Finance Ministers and Central Bank Governors’ (2011) 3 <https://www.fsb.org/wp-content/uploads/r_1103.pdf> accessed 8 September 2019.

${ }^{146}$ Bank of England, 'Instruments of Macroprudential Policy - A Discussion Paper' (2011) 26.

${ }^{147}$ Armour and others (n 141) 424.
} 
to address cross-sectional risk, such as the imposition of central counterparties, may drive market participants to unregulated parts of the financial system. This is what led to the development of the 'shadow banking' system prior to the GFC. Accordingly, it can be seen that imposing regulation informed by a more realistic intellectual framework is not without its challenges.

\section{HAVE THE LESSONS FROM THE FINANCIAL CRISIS BEEN FOLLOWED?}

This article now evaluates instances of post-GFC financial regulation to understand whether policymakers and regulators have internalised the lessons taught by the crisis discussed in Part C. To do so, this article examines the development of disclosure regulation, specifically in relation to retail investors, to understand whether it incorporates lessons from behavioural economics. Then it examines the shift towards the macroprudential approach by Basel III.

\section{Disclosure and Investor Protection}

As discussed, prior to the GFC, it was assumed that market participants are rational with unlimited computational ability. Disclosure of relevant information, in turn, was thought to enhance decision-making, improve market efficiency and enable market discipline. However, as has been outlined, market participants are only boundedly rational and there are limits to the efficacy of disclosure. This is not to say that disclosure is not an important regulatory tool, rather regulators and policymakers should be cognisant of how market participants process information. This, in turn, may necessitate adjusting both the level of information disclosed and how it is presented. ${ }^{148}$ The relevant question, therefore, is whether post-GFC disclosure regulation recognises the limits of disclosure in light of market participants' bounded rationality, or whether the pre-crisis 'disclose and self-regulate' approach is still present.

One notable development has been in relation to the quality of disclosure to retail investors. For instance, European regulators now require issuers to produce simplified disclosure documents that provide information about the financial product being sold. The 2009 Undertakings for Collective Investment in Transferable Securities (UCITS) IV Directive introduced the 'Key Investor Information Document' (KIID), which replaced the simplified prospectus mandated by

\footnotetext{
148 Avgouleas, 'The Global Financial Crisis and the Disclosure Paradigm' (n 37) 468.
} 
UCITS III. ${ }^{149}$ This initial simplified prospectus only shortened the main, lengthy prospectus and did not address format issues or assist investors in making difficult decisions regarding, for example, past performance. ${ }^{150}$ However, 'in most cases, the document... [was] too long and not understood by its intended readers'. ${ }^{151}$ In contrast, the KIID adopted by UCITS IV (as amended by UCITS V) is a two-page document that outlines the objectives of the investment, provides a synthetic risk/reward indicator on a scale of one to seven, discloses the issuer's fees and any other charges, and provides a graphical representation of past performance over the previous 10 years. This development reflects a greater level of sensitivity to the limits of disclosure and the lessons from behavioural economics. Indeed, the EU Commission tested the KIID in a behavioural study to understand how best to present the information to consumers. ${ }^{152}$

The requirement for a short-form information document has been extended to other investment products and reformed post-GFC. Under the Packaged Retail and Insurance-based Investment Products (PRIIPs) Regulation, a similar document, the Key Information Document (KID) is required for PRIIPs, which are investment products where the investor is exposed to changes in a reference value or the performance of an asset, such as non-UCITS schemes, debt securities (including bonds and notes) and structured investments. The content of a PRIIPS KID is more extensive than a UCITS KIID. The PRIIPS KID is three-pages long, as opposed to two, and covers questions including: 'what is this product?'; 'what are the risks and what could I get in return?'; 'what happens if the PRIIP manufacturer is unable to pay out?'; 'what are the costs?'; and, 'how long should I hold it and can I take money out early?' Notably, the PRIIPs KID replaces historical performance data with forward-looking performance scenarios, showing different levels of returns under different market conditions (i.e. favourable, moderate, and unfavourable). Eventually, the PRIIPS KID will replace the KIID for UCITS schemes. ${ }^{153}$

\footnotetext{
${ }^{149}$ Directive 2009/65/EC of the European Parliament and of the Council of 13 July 2009 on the coordination of laws, regulations and administrative provisions relating to undertakings for collective investment in transferable securities [2009] OJ L 302/32 (UCITS).

${ }^{150}$ Moloney (n 40) 314.

151 Commission of the European Communities, 'White Paper on Enhancing the Single Market Framework for Investment Funds' (2006) COM(2006)686 10.

152 IFF Research and YouGov, 'UCITS Disclosure Testing Research Report' (2009) <http://ec.europa.eu/internal_market/investment/docs/other_docs/research_report_en.pdf> accessed 26 August 2018.

153 Regulation (EU) No 1286/2014 of the European Parliament and of the Council of 26 November 2014 on key information documents for packaged retail and insurance-based investment products (PRIIPs) [2014] OJ L 352, article 32.
} 
The introduction of more user-friendly disclosure documents should, in theory, improve understanding of financial products by retail investors, and assist them in navigating the complexity of these products. However, there are notable problems with KIID/KIDs. First, although the UCITS KIID was subject to consumer testing to improve comprehension, ${ }^{154}$ a US study found that the SEC's summary prospectus - which, similar to the KIID/KID, outlines the principal investment strategies, principal risks, historical returns and fees in a short document- did not impact the investors' portfolio choices. ${ }^{155}$ Therefore, as Avgouleas states, the KIID/KID may not impact investors' decision-making. ${ }^{156}$ Second, capturing the complexity of such a range of products in a three-page summary may result in important nuance being removed. ${ }^{157}$ Thus, the KIID/KID may become an oversimplified heuristic that retail investors over-rely upon and thus not provide the intended protection for investors and the market. Third, the new forward-looking performance indicators have been criticised for being over-optimistic and misleading, given that the stated future returns are projections based on the fund's previous five years' performance. ${ }^{158}$ Indeed, as investment funds' performance has benefitted from strong markets in the past five years, these projections do not truly reflect the consequences of a repeat of the GFC, if it were to occur. Nevertheless, despite criticism, use of the KIID/KID reflects a shift in attitude towards disclosure away from the pre-crisis rational investor model and towards a more behavioural model.

\section{Basel III}

Basel II adopted a firmly microprudential approach to capital adequacy, focussing on the safety of individual banks. However, as outlined in Part B, Basel II was flawed for numerous reasons, including being procyclical and allowing banks to use their own flawed models for the purposes of determining regulatory capital, which enabled banks to arbitrage the capital adequacy rules to lower their capital costs. The GFC subsequently revealed that banks were undercapitalised and overleveraged, with insufficient liquidity buffers. ${ }^{159}$ However, post-GFC, there has been a notable

\footnotetext{
${ }^{154}$ Directorate-General for the Internal Market and Services and London Economics, 'Consumer Testing Study of the Possible New Format and Content for Retail Disclosures of Packaged Retail and Insurance-Based Investment Products Final Report' (2015).

155 John Beshears and others, 'How Does Simplified Disclosure Affect Individuals' Mutual Fund Choices?' [2009] NBER Working Paper No w14859.

156 Avgouleas, 'The Global Financial Crisis and the Disclosure Paradigm' (n 37) 469.

${ }^{157}$ Niamh Moloney, EU Securities and Financial Markets Regulation (3rd edn, OUP 2014) 821.

158 John Kay, 'Risk, the Retail Investor and Disastrous New Rules' (Financial Times, 19 January 2018) <https://www.ft.com/content/f1513818-fa06-11e7-9bfc-052cbba03425> accessed 27 August 2018.

159 BCBS, 'The Basel Committee's Response to the Financial Crisis: Report to the G20' (2010) 1 <https://www.bis.org/publ/bcbs179.pdf> accessed 21 August 2018.
} 
shift towards the macroprudential approach, which reflects the wider acceptance of the FIH. ${ }^{160}$ Indeed, Basel III was introduced to address the issue of procyclicality and recognises the interlinkages and common exposures between banks. ${ }^{161}$ Nonetheless, microprudential tools remain present in Basel III, with efforts to improve the resilience of individual banks through higher capital adequacy requirements and capital buffers. Specifically, Basel III has introduced additional requirements for institutions to maintain a capital conservation buffer, countercyclical buffer, and has imposed a capital surcharge for systemically important financial institutions. Basel III has also changed the leverage ratio. Thus, it seems Basel III adopts a macroprudential approach using largely microprudential tools. ${ }^{162}$ It follows that Basel III adopts an almost hybrid approach to systemic risk. Whilst adopting a more macroprudential approach is positive, it remains that the tools of Basel III are still microprudential in nature and build upon those used in Basel II. The consequent danger is that Basel III is susceptible to the same inherent flaws as Basel II. ${ }^{163}$

Basel III retains minimum capital requirements and the use of risk weighted assets (RWAs). However, whilst the total capital requirement remains at 8 per cent of the total RWAs, Tier One capital has increased from 4 per cent under Basel II to 6 per cent under Basel III. ${ }^{164}$ Tier One capital now comprises of 4.5 per cent of common equity and/or retained earnings, compared with 2 per cent under Basel II. ${ }^{165}$ This increase in higher quality capital, consequently, improves the resilience of banks in a financial downturn. Further, the higher quality capital also bolsters the strength of the capital conservation buffer and countercyclical buffer (as discussed below). ${ }^{166}$ However, the continued use of RWAs undermines minimum capital requirements and the additional buffers - a problem caused by building on Basel II. Whilst limits have been placed on the extent to which banks' financial models can be used to assess risk, ${ }^{167}$ historically, and as seen in the GFC, banks are committed to regulatory capital arbitrage to reduce their capital costs. ${ }^{168}$

\footnotetext{
160 Emilios Avgouleas, 'Bank Leverage Ratios and Financial Stability: A Micro- and Macroprudential Perspective' [2015] Levy Economics Institute of Bard College Working Paper No. 8493.

161 Jamie Caruana, 'Basel III: Towards a Safer Financial System'<https://www.bis.org/speeches/sp100921.pdf> accessed 20 August 2018.

162 Armour and others (n 141) 416.

163 ibid 418.

164 BCBS, 'Basel III: A Global Regulatory Framework for More Resilient Banks and Banking Systems’ (2010) 12.

165 ibid.

166 Andenæs and Chiu (n 13) 341.

${ }^{167}$ BCBS, 'High-Level Summary of Basel III Reforms' (2017) 5.

${ }^{168}$ Erik F Gerding, 'The Dialectics of Bank Capital: Regulation and Regulatory Capital Arbitrage' 55 Washburn Law Journal 29.
} 
Indeed, under Basel I and II, securitised assets attracted lower capital charges than the nonsecuritised underlying assets. Accordingly, the pre-crisis increase in securitisation has been attributed to Basel II. ${ }^{169}$ Thus, it remains plausible that banks both alter internal models to lower RWA calculations ${ }^{170}$ and identify assets that incur lower capital charges, enabling higher leverage. Therefore, whilst improvements to minimum capital requirements and introduction of capital buffers improve banks resilience in a financial downturn, they are fundamentally undermined by the continued use of RWAs.

The capital conservation buffer (CCB) and countercyclical buffer (CB) are also intended to mitigate procyclicality. ${ }^{171}$ The CCB requires banks to hold an additional 2.5 per cent of Tier One common equity from its total RWAs. The CCB is 'designed to ensure banks build up capital buffers outside periods of stress which can be drawn down as losses are incurred'. ${ }^{172}$ The intended effect is that banks will be able to draw on the CCB in the event of a downturn, when they would otherwise decrease lending and reduce the size of their balance sheets. This reflects an important lesson from the FIH, as restrictions in credit availability causes speculative and Ponzi finance units to fail. If a bank fails to hold this additional $2.5 \%$ (i.e. its Tier One common equity drops into the $\mathrm{CCB}$ ), then it will not be able to make distributions, such as paying dividends or the equity portion of compensation packages. This incentivises higher capital requirements in 'good times', when banks want to make such distributions. But it also provides an adverse incentive to shareholders and managers in downturns to build the CCB by restricting lending and shrinking their balance sheet. ${ }^{173}$ Thus, the CCB has seemingly not solved the problem of restrictive lending practices in downturns. To address this problem, the CCB should require banks build up an absolute level of capital before making distributions. ${ }^{174}$ Otherwise, the CCB may not improve conditions during the downturn.

The CB is a time-varying capital buffer that ranges between an additional 0 and 2.5 per cent of a bank's RWAs in Tier One capital. ${ }^{175}$ The CB is triggered by national regulators when

\footnotetext{
169 Avgouleas, 'Bank Leverage Ratios and Financial Stability' (n 160) 14.

${ }^{170}$ David Henry and Lauren Tara LaCapra, 'Analysis: JPMorgan and Other Banks Tinker with Risk Models' Reuters (18 March 2013) <https://uk.reuters.com/article/us-banks-capital/analysis-jpmorgan-and-other-banks-tinker-withrisk-models-idUSBRE92H02I20130318> accessed 23 August 2018.

${ }^{171}$ BCBS, 'The Basel Committee's Response to the Financial Crisis' (n 159) 9.

172 BCBS, 'Basel III' (n 164) 54.

173 Armour and others (n 141) 307.

${ }^{174}$ Bank of England, 'Instruments of Macroprudential Policy' (n 146) 23.

175 BCBS, 'Basel III’ (n 164) 58.
} 
there is an increase in systemic risk during a period of excessive credit growth, which is intended to prepare banks for an economic downturn and moderate the harshness of the credit cycle. ${ }^{176}$ The purpose is to increase the overall strength of the financial system as the cycle progresses, whilst reducing lending in the upswing and providing a capital cushion in the downturn. ${ }^{177}$ The amount of the buffer depends on the amount of the systemic risk, with the measure being credit-to-GDP, which reflects the increasing risk in the financial system as a whole rather than in individual banks $^{178}$ - a positive shift towards macroprudentialism. Indeed, in the build-up to the crisis, the credit-to-GDP ratio in the UK increased significantly, before suddenly declining in 2007, therefore making it a relatively accurate tool in retrospect. ${ }^{179}$ However, whilst there are other measures established under Basel III to identify excessive credit grow such as asset prices and real GDP growth, ${ }^{180}$ it remains difficult to identify credit bubbles or the build-up to a systemic crisis ex ante. Conversely, stress testing banks' balance sheets, which involves simulating banks performance in various crises, can inform the decision to increase the CB. For example, a stress test in 2017 caused the Bank of England to increase the CB. ${ }^{181}$ But stress tests are not infallible; scenario planning may ignore unforeseen events and not capture the full range of possibilities. ${ }^{182}$ In other words, stress tests are necessarily limited by the quality of the inputted scenarios. Additionally, regulators themselves may also become euphoric or pressured to reduce banks' capital charges in periods of growth. Therefore, the $\mathrm{CB}$ is potentially useful in attenuating the credit cycle, but somewhat undermined by the difficulties in deploying it effectively.

The introduction of a leverage ratio under Basel III represents a notable shift towards the macroprudential approach and addresses procyclicality. As explained by the FIH, progressively higher levels of leverage in the financial system is symptomatic of a structural shift towards a system comprising mostly of speculative and Ponzi finance units that increases financial fragility. This excessive leverage was a contributing factor to the GFC and fuelled asset bubbles across the financial system. When financial institutions deleveraged, it caused asset prices to spiral

\footnotetext{
176 ibid 57.

177 Bank of England, 'The Financial Policy Committee's Review of the Leverage Ratio' (2014) 30 <https://www.bankofengland.co.uk/financialstability/Documents/fpc/fs_lrr.pdf> accessed 22 August 2018.

178 Avgouleas, Governance of Global Financial Markets (n 34) 325.

${ }^{179}$ Bank of England, 'Leverage Ratio' (n 177) 29.

${ }^{180}$ BCBS, 'Guidance for National Authorities Operating the Countercyclical Capital Buffer' (2010) 4.

${ }^{181}$ Bank of England, 'Stress Testing the UK Banking System: 2017 Results' (2017) 5.

182 Andenæs and Chiu (n 13) 353.
} 
downwards, creating a 'credit crunch'. ${ }^{183}$ In response, Basel III has introduced a non-risk-based leverage ratio of $3 \%$ of Tier 1 capital. ${ }^{184}$ The fact the leverage ratio is non-risk-based means it serves as a backstop against 'gaming' risk-based capital requirements or model risk arising from calculating a bank's RWAs. The purpose of this ratio is to limit the build-up of leverage and supplement the capital adequacy requirements, and it encompasses both on and off-balance sheet liabilities. ${ }^{185}$ This addresses the possibility of banks moving leverage off-balance sheet, as seen in the GFC. More broadly, the leverage ratio limits the extent to which irrational exuberance can lead financial institutions to overleverage themselves during the 'boom' period and incorporates the FIH. ${ }^{186}$ A corollary of limiting leverage in the 'boom' period is that when financial institutions deleverage in the 'bust' period, it has a less drastic impact on the financial system. ${ }^{187}$

Whilst the leverage ratio is theoretically effective in mitigating the negative impact of financial downturns, and avoids the problems associated with RWAs as it is non-risk-based, it is not sufficient in itself to replace risk-based capital requirements. Indeed, the leverage ratio can still be manipulated by opting for a riskier, higher yield portfolio which does not require additional capital relative to a lower risk portfolio - a practice known as risk shifting, ${ }^{188}$ as seen in the US. ${ }^{189}$ This is because it is the risk that changes and not the value of the portfolio. Therefore, the risk insensitivity of the leverage ratio is both an advantage and disadvantage, necessitating both risk and non-risk-based tools. Nevertheless, its introduction reflects the shift towards the macroprudential approach and internalisation of the FIH by regulators and policymakers.

\section{E. CONCLUSION}

The financial crisis revealed that the use of modern finance theory as the intellectual framework for financial regulation is not viable. Indeed, the events of the GFC demonstrate that financial markets are not always efficient and rational, contrary to the prevailing beliefs held by regulators and policymakers before the crisis. Accordingly, this article examined how modern finance theory

\footnotetext{
183 BCBS, 'Basel III' (n 164) 60.

184 ibid.

185 ibid 61.

${ }^{186}$ Cullen (n 63) 206.

187 Avgouleas, Governance of Global Financial Markets (n 34) 332.

${ }^{188}$ Armour and others (n 141) 304; Bank of England, 'Leverage Ratio' (n 177) 12.

189 Tracy Alloway, 'US Banks Take on More Risk as New Rules Bite' Financial Times (New York, 16 January 2014) <https://www.ft.com/content/d843912e-7dfd-11e3-95dd-00144feabdc0> accessed 21 August 2018.
} 
influenced and undermined the pre-crisis regulatory approach, and whether post-crisis regulation reflects a more accurate view of the financial system.

Part B outlined the EMH and examined its influence on the pre-crisis regulatory approach. The EMH and assumption of investor rationality led to a disclosure-paradigm that was focussed on producing an abundance of information but did not consider if such information could, or would, be utilised effectively by market participants. As set out, the pre-crisis understanding that markets are efficient and rational informed the reliance on market discipline. This is exemplified by Basel II, which utilised disclosure-based market discipline to manage financial institutions' capital adequacy. Thereafter, a solely microprudential approach was adopted on the assumption that market discipline could constrain risk-taking.

Part C examined how the events of the GFC caused the pre-crisis approach to unravel, and thus provided important lessons for post-GFC regulation. Market discipline failed to signal elevated risk in the financial system and rein in risk-taking as expected. Using a behavioural critique of the failure of market discipline, it can be seen that complexity undermined disclosure and precipitated complacency, which manifested itself as over-reliance on heuristics and herd behaviour. This led to asset prices deviating from their fundamental value, contrary to the EMH. Therefore, it cannot be assumed that market participants are always rational and rationally adjust their expectations on the basis of the available information, which undermines the extent to which market discipline can be relied upon. Further, the problem of conflating the EMH into a statement that all markets are efficient led to the false assumption that money market investors would impose market discipline. In reality, they are informationally insensitive for most of the cycle. Part C concluded that the relative accuracy of the FIH, along with the evident flaws with the pre-crisis microprudential approach, necessitates a more macroprudential approach.

Part D evaluated instances of post-GFC financial regulation in light of Part C. It found that the introduction of the key investment document by the UCITS and PRIIPs regulations incorporates behavioural economics and reflects the fact that investors are not unboundedly rational, though the PRIIPs KID is somewhat flawed. Further, we saw that Basel III positively addresses procyclicality and seemingly internalises the FIH, but the new capital buffers are fundamentally undermined by the retained usage of risk-weighted assets, which can be gamed. This is somewhat offset by the introduction of a non-risk-based leverage ratio. 
In conclusion, post-crisis regulation appears to reflect the lessons from the crisis on using modern finance theory as the intellectual framework for financial regulation, and a more realistic view of the financial system. Nevertheless, two issues remain moving forward. First, regulators and policymakers may regress to pre-crisis thinking or succumb to pressure to deconstruct postcrisis regulation. ${ }^{190}$ Second, in responding to pre-crisis regulatory failings, the post-crisis regulatory approach may underestimate or miss factors that will contribute to the next crisis. Therefore, until the next crisis, it remains to be seen whether the lessons from the financial crisis were truly followed.

190 Barney Jopson, ‘US Congress Rolls Back Parts of Post-Crisis Bank Rules’ Financial Times (London, 22 May 2018) <https://www.ft.com/content/649e6d66-5deb-11e8-ad91-e01af256df68> accessed 25 July 2018. 